\title{
Urdimento
}

Revista de Estudos em Artes Cênicas

E-ISSN: 2358.6958

\section{Crianças nas artes performativas: conversa com Meredith Monk}

Entrevista com Meredith Monk concedida à Melissa da Silva Ferreira

\section{Para citar este artigo:}

FERREIRA, Melissa da Silva. Crianças nas artes performativas: conversa com Meredith Monk. Urdimento, Florianópolis, v. 3, n. 39, nov./dez. 2020.

DOI: http:/dx.doi.org/10.5965/14145731033920200504 


\title{
Crianças nas artes performativas: conversa com Meredith Monk
}

Entrevista com Meredith Monk concedida à Melissa da Silva Ferreira ${ }^{1}$

\begin{abstract}
Resumo
Nesta entrevista, a artista estadunidense Meredith Monk fala sobre o seu percurso nas artes performativas e, mais especificamente, a participação de crianças em suas obras. Monk trata de temas como o budismo, os caminhos e as escolhas como artista, as artes da presença, o envelhecimento e as noções de tradição e legado.
\end{abstract}

Palavras-chave: Meredith Monk. Artes performativas. Crianças. Arte.

\section{Children in the performing arts: conversation with Meredith Monk}

\begin{abstract}
In this interview, the American artist Meredith Monk talks about her path in the performing arts and, more specifically, the participation of children in her works. Monk also addresses topics such as Buddhism, the artist's choices and paths, the live arts, aging and the notions of tradition and legacy.
\end{abstract}

Keywords: Meredith Monk. Performing arts. Children. Art.

\section{Los niños en las artes escénicas: conversación con Meredith Monk}

\section{Resumen}

En esta entrevista, la artista estadounidense Meredith Monk habla de su trayectoria en las artes escénicas y, más concretamente, de la participación de los niños en sus obras. Monk trata temas como el budismo, los caminos y las elecciones como artista, las artes de la presencia, el envejecimiento y las nociones de tradición y legado.

Palabras clave: Meredith Monk. Las artes escénicas. Niños. Arte.

${ }^{1}$ Pós-doutoranda no Programa de Pós-Graduação em Artes da Cena da Universidade Estadual de Campinas (UNICAMP). Bolsista da Fundação de Amparo à Pesquisa do Estado de São Paulo, processo FAPESP 2017/11886-0. mellunar@hotmail.com 
Figura 1 - Meredith Monk e Melissa Ferreira. Nova York. 2020

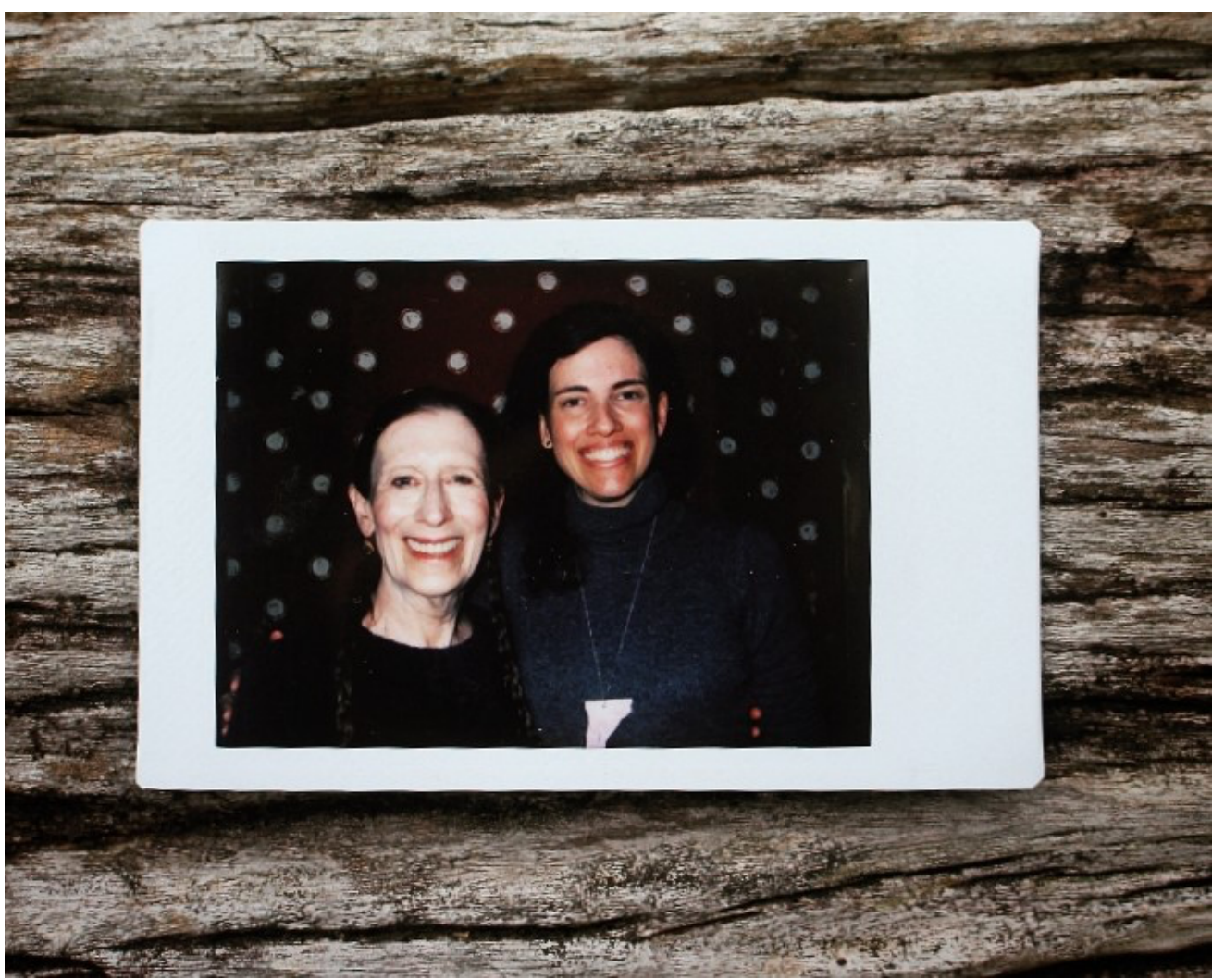

Esta entrevista ${ }^{2}$ foi conduzida no contexto do estágio de pesquisa realizado no Martin E. Segal Center da City University of New York, como parte do projeto de pós-doutorado intitulado Presenças da Infância na Cena Contemporânea ${ }^{3}$ desenvolvido desde maio de 2018 no Programa de Pós-graduação em Artes da Cena da Universidade Estadual de Campinas. O objetivo do projeto é investigar as relações e parcerias artísticas entre crianças e artistas no campo das artes performativas contemporâneas.

A artista interdisciplinar Meredith Monk (1942-) é reconhecida como um dos nomes mais importantes da vanguarda artística estadunidense. Suas experimentações como performer, cineasta, coreógrafa, diretora teatral e

\footnotetext{
${ }^{2}$ Entrevista realizada no dia 28 de janeiro de 2020, em New York City (EUA).

${ }^{3}$ Apoio da Fundação de Amparo à Pesquisa do Estado de São Paulo - FAPESP, processo FAPESP 2017/11886-0.
} 
compositora foram pioneiras em borrar as fronteiras entre as artes visuais, a música, o teatro, a dança e o vídeo nos anos 1960 nos Estados Unidos.

As crianças são presenças constantes nos trabalhos de Monk. Elas aparecem como colaboradoras, performers ou personagens em obras icônicas como Children (1967), Juice: a theatre cantata in three installments (1969), Education of the Girlchild (1972), Quarry. An Opera in Three Movements (1976), Book of Days (1989) e ATLAS: an opera in three parts (1991), e mais recentemente em Dancing Voices (2010, 2017) e Cellular Songs (2018).

$\mathrm{Na}$ conversa a seguir a artista fornece pistas valiosas para entender sua relação com as crianças. Para Monk, o que um artista pode aprender ao colaborar com uma criança é "estar completamente presente no momento" e "ver as coisas sempre de uma maneira nova". E o que ela tenta transmitir às crianças e jovens com quem trabalha é "uma filosofia de vida, uma maneira de pensar sobre as coisas, uma maneira de pensar sobre a nossa relação com a vida" e não uma técnica em particular. Uma das noções que emerge na fala da artista é a da criança como o "puro contemporâneo"*. Contemporâneo no sentido de adesão subjetiva e histórica ao tempo presente, mas também no sentido atribuído por Giorgio Agamben (2001) como algo que nos é obscuro. Para Agamben a infância não é apenas uma etapa cronológica, mas uma condição singular da experiência. Em Book of Days, filme dirigido por Monk em 1989, a personagem criança aparece como visionária, uma outsider da sociedade que vê o futuro e, com isso, revela as obscuridades do tempo presente. O espetáculo teatral Quarry gira em torno dos pesadelos de guerra da personagem criança representada por Monk. Em seu trabalho mais recente, Cellular Songs, a criança representa a possibilidade de continuidade frente aos ciclos de morte e vida.

Termo usado pela pesquisadora das infâncias Anete Abramowicz (2016). Inspiradas na noção de "contemporâneo" de Agamben, para Anete Abramowicz e Fabiana Oliveira, a criança "não é só o presente que ela inscreve em si", ela traz o passado - o dos adultos; elas "anunciam também e são portadoras de um futuro, do devir, mas também são a fissura, o corte e a descontinuidade. A infância é um encontro entre os tempos e as gerações, e as descontinuidades. [...] O que a criança fala, diz e age, a maneira pela qual ela subjetiva o mundo, nos diz de um presente que conhecemos e podemos decifrar, mas também nos é obscuro, por isto contemporâneo." (Abramowicz; Oliveira, 2010, p. 45). 
Em seis meses em Nova York, encontrei Monk três vezes e estes encontros dizem muito sobre o seu espírito incansável. O primeiro foi na sua festa de aniversário de setenta e sete anos, celebrada numa casa de shows alternativa no Brooklyn com performances de drag queens, DJs e pista de dança. O segundo encontro aconteceu na exibição do filme restaurado da peça Quarry. Nosso terceiro encontro aconteceu para esta entrevista apenas dois dias antes de eu deixar Nova York. Na conversa, além de falar sobre as suas colaborações artísticas com crianças, Monk tocou também em outros temas, como o budismo, as escolhas e os caminhos do artista, as artes da presença, o envelhecimento e as noções de tradição e legado, o que nos dá uma bela, sensível e profunda perspectiva da sua carreira de mais de cinquenta anos dedicados às artes.

\section{Você poderia começar falando sobre o espetáculo Dancing Voices produzido no Lincoln Center em 2017?}

Sim. Esse foi um projeto com o Young People's Chorus of New York City. Dez anos atrás eu ensinei para as crianças do YPC duas partes de Three Havens and Hells. Three Heavens and Hells foi a primeira peça em que eu compus música a partir de um poema. O poema foi escrito por uma menina de onze anos, que é adulta agora. Tennessee Reed foi uma criança muito interessante. Eu ainda sou muito próxima dela. Eu realmente adoro trabalhar com as crianças. Em 2010, eu ensinei para elas [Young People's Chorus of New York City] ${ }^{6}$ duas partes de Three Heavens and Hells. Eu acho até que fizemos um pouco mais, mas nunca fizemos a peça inteira. Então, ao longo dos anos, eu e Francisco ${ }^{7}$ sempre falamos: "Não seria legal fazer todas as partes de Three Heavens and Hells num único espetáculo?" Na verdade, perdão, eu acho que provavelmente eu comecei a trabalhar com o Young People Chorus of New York antes de 2010, talvez em 2007 ou 2008. Então o que aconteceu foi que em 2010 eu fui convidada para trabalhar

\footnotetext{
${ }^{5}$ A obra musical de 1992, composta em sete partes, foi inspirada num poema escrito por Tennessee Reed (na época com onze anos). Reed é filha do escritor Ishmael Reed.

${ }^{6}$ As informações entre colchetes foram acrescentadas pela entrevistadora, e tradutora, para auxiliar no entendimento de alguns trechos da conversa.
}

${ }^{7}$ Francisco Núñez, diretor artístico e maestro do Young People's Chorus of New York City. 
com um grupo de crianças na Bélgica. Foi muito interessante fazer um concerto inteiro com um coral de crianças. Eu acho que eram vinte e uma crianças. Nós fizemos um concerto intitulado Dancing Voices. Então eu voltei para New York e disse para o Francisco: "Nós fizemos um concerto lindo, o Dancing Voices. Você não gostaria de fazer com as suas crianças?" Demorou vários anos para organizarmos isso. Nós colocamos cem pessoas no palco ${ }^{8}$. Foi uma experiência incrível. Katie ${ }^{9}$, Allison ${ }^{10}$ e eu cantávamos com os menores do grupo. Eles eram muito bons. Nós estávamos cantando e uma das crianças, um menino de nove ou dez anos, disse: "Katie, você está um pouco abaixo", no tom da voz. Katie Geissinger é uma cantora maravilhosa, realmente muito boa. Nós ficamos: "Uau! Nós temos que nos dedicar para cantar com essas crianças." Foi tão fofo. Este era um grupo formado por meninas e meninos cujas vozes ainda não tinham mudado. Para as meninas, eu acho que catorze era a idade máxima; e para os meninos, talvez doze. Eram todas músicas [para vozes] agudas. E para ensinálos a se mover com todos aqueles gestos? E a presença? Porque, muitas vezes, em corais, crianças e adultos apenas ficam em pé com a partitura em frente a eles. Não é uma coisa teatral. Então eles tiveram que realmente manter a concentração. Alguns deles eram bem pequenos, oito, nove, dez anos de idade. Para mantê-los concentrados foi muito desafiador, mas foi muito divertido trabalhar com eles. Foi uma relação muito profunda e muito nova, como se pode perceber nas entrevistas ${ }^{11}$. Eu sempre quis fazer de novo, mas até agora nós não tivemos outra chance de fazer com o YPC. Pelas agendas, é muito difícil, mas eu adoraria continuar. Agora, na verdade, eu estou trabalhando numa nova obra e eu estou pensando que talvez a última imagem que eu quero nesta peça é de uma criança. Eu não tenho filhos, mas minha irmã tem quatro filhos. Uma das minhas sobrinhas mora aqui em Nova York. Ela tem duas crianças, a menina tem

\footnotetext{
8 Lincoln Center.
}

9 Katie Geissinger, cantora. Trabalha com Meredith Monk desde 1990. Integrou o elenco da remontagem de Einstein on the Beach, ópera de Robert Wilson e Philip Glass, em 1992.

10 Allison Sniffin, multi-instrumentista, cantora e compositora. Integra o Meredith Monk \& Vocal Ensemble desde 1996.

11 No documentário Behind the Scenes (2010) produzido pelo Lincoln Center para registar os ensaios e apresentações de Dancing Voices. 
sete anos e o menino quatro. Desde que a menina tinha três, eu tenho escrito canções de aniversário para os dois. As duas crianças são super musicais. Eu estou tentando fazer com que eles amem música, porque a minha sobrinha e o marido dela gostam tanto, mas por alguma razão eles não conseguem cantar ou tocar, o que é inédito na minha família. Minha mãe teria um ataque do coração. [risos]. Então eu tenho escrito essas canções de aniversário para eles. A minha sobrinha-neta estava aqui tocando alguma coisa no piano e eu fiz a notação disso e pensei: "Seria lindo pegar essa pequena melodia que ela tocou e adicionar outras partes a ela." E então eu estou pensando que poderia ser o fim da minha nova peça. Eu ainda não tenho certeza, mas de qualquer maneira, há essa ideia de uma criança tocar essa pequena melodia no piano e depois apenas ficar ali de pé ou fazer algo bem simples, fazer um desenho ou algo assim... Porque eu sinto que nós estamos tão preocupados com o futuro que parece importante afirmar que haverá um futuro. E, de qualquer maneira, parece que isso seria algo bonito de se ter no fim desta peça. Isso é uma coisa que está na minha cabeça o tempo todo. Eu acho que eu sempre senti que ter uma criança como personagem numa peça, mesmo interpretada por um adulto, tem a ver com a ideia de ver as coisas sempre de uma maneira nova e de ter um espírito brincalhão mesmo para as coisas mais sérias. A brincadeira como um elemento da vida é um tipo de lição para todos nós. E, também, [um modo de] estar muito presente no momento. Eu sempre achei que há um mal-entendido: as pessoas não sabem a diferença entre ser childish e childlike. Childish significa ser meio bobo, não pensar ou não ter força. Mas childlike é como se você fizesse a escolha de entrar naquele tipo de mentalidade [da criança]. É muito sofisticado.

\section{Eu vi os vídeos "Behind the Scenes" do Dancing Voices e me chamou atenção a sua relação com as crianças performers.}

Eu acho que foi ótimo compartilhar o palco com elas. Eu acho que isso foi algo que nos aproximou muito. Elas realizam muitos trabalhos de compositores, mas geralmente os compositores vêm para um ensaio e as crianças continuam fazendo seu trabalho e nunca mais os veem. Nós estávamos no palco com 
aquelas crianças, neste lugar tão vulnerável... Ali de pé ao lado delas, e elas estavam cantando tão lindamente, eu senti que elas eram minhas parceiras. Há algo sobre isso que foi muito emocionante: estar no mesmo palco e cantar com elas. Houve, por exemplo, uma situação na Bélgica em que uma das crianças cometeu um erro tremendo em cena e eu e a outra criança tivemos que descobrir o que fazer. Esse tipo de coisa... a vulnerabilidade disso. Eu me sinto muito vulnerável como performer. Eu acho que como artista mais jovem, talvez na minha meia-idade, eu sentia que esse era o meu lugar de poder no mundo, mas à medida que envelheci, como pessoa fiquei mais vulnerável e acho que como artista também. E acho que a vulnerabilidade é algo a ser valorizado, na verdade, a ser incentivado. Porque acho que quando você vê um artista vulnerável, algo maravilhoso realmente está acontecendo lá. É, novamente, sobre estar muito presente. E essa vulnerabilidade só pode acontecer em performances ao vivo. Em gravação ou filme é diferente. Acho que havia [ali] algo sobre compartilhar aquela emoção que era muito profunda, compartilhar aquele espaço. Um vínculo muito profundo. Algumas dessas crianças ainda estão em contato comigo. Eu sinto muita falta delas. A primeira vez que eu ensaiei com a adolescente que faz o dueto comigo, eu literalmente comecei a chorar. Eu nem sabia se seria capaz de me apresentar com ela. Ela acabou participando da minha ópera. Foi ideia do Francisco. Ela acabou interpretando a jovem Alexandra em ATLAS. Ela foi incrível. Treze anos de idade. Realmente forte. É tão íntimo performar juntos. Tão íntimo. Pelo menos para mim. Estou olhando nos olhos da outra pessoa, estamos compartilhando energia, estou tentando dar minha energia para que ela se sinta confortável com tudo o que está acontecendo. É uma interação humana muito profunda.

\section{Eu queria também perguntar sobre a performance na Bélgica.}

Não tinha negros [people of collor]! Todo mundo na Bélgica é loiro? Isso foi muito difícil para mim. Em Cellular Songs... Você viu as crianças e jovens em Cellular Songs? Dez jovens meninas sobem ao palco conosco no final da peça. A nossa ideia é: somos cinco mulheres e então chamamos cinco adolescentes e 
cinco meninas pequenas. Sentimos que estamos passando nosso DNA, nossas células musicais [cellullar songs] para elas. Elas se juntam a nós no final [do espetáculo]. Em cada lugar que apresentamos contatamos um coro local de onde vem as meninas e jovens mulheres. Em alguns lugares nos Estados Unidos, porém, só aparecem pessoas brancas e isso tem sido muito estranho, porque nunca foi essa a ideia. A ideia era ter pessoas de todos os tipos. Nós realmente insistimos, mas estou the dizendo, às vezes é realmente desafiador. Na Bélgica, ficamos chocados porque Katie Geissinger, quando liderava audições com crianças, disse: "Nenhuma criança negra sequer aparece nas audições". Ter somente crianças loiras foi um pouco decepcionante para mim, mas ainda assim era um belo grupo de crianças. Foi a minha primeira tentativa de fazer uma peça inteira com crianças. E elas tinham uma maestrina ${ }^{12}$ maravilhosa. Isso também faz uma enorme diferença: um maestro não ameaçador e que trabalhe com as crianças no material antes de chegarmos lá. Recentemente nós fizemos Cellular Songs nas áreas de Los Angeles e San Francisco. As crianças estavam muito preparadas, elas conheciam a música, não tínhamos que começar desde o início, então podíamos realmente trabalhar com elas na encenação e tudo mais. Porque é muito, muito preciso. A encenação é muito precisa. E você tem que estar muito presente, porque é muito transparente. Não há muitos cenários, você vê cada criança andando e como elas andam, você vê tudo. Essa foi a última coisa que fizemos com crianças e jovens. Foi muito especial.

Minha pergunta era justamente sobre a diferença entre os dois grupos de crianças, belgas e estadunidenses. Eu assisti os vídeos e eu tenho a impressão de que as crianças na Bélgica se comportam mais espontaneamente no palco...

Na Bélgica? Sério? [risos] Eu diria o contrário, mas vá em frente, eu quero muito ouvir a sua impressão...

No grupo da Bélgica uma das crianças estava rindo em cena, outra estava se movimentando livremente... As crianças do YPC parecem tão profissionais no palco...

${ }^{12}$ Marleen de Boo, maestrina do Waelrant Children's Choir da Antuérpia (Bélgica). 
Elas são bem profissionais. Elas se apresentam em muitos lugares. Eu acho que as crianças do coro da Bélgica já tinham se apresentado antes, mas O YPC se apresentou até para o presidente dos Estados Unidos. De certa forma elas são um pouco mais profissionais. Sim, elas são! Eu acho que sim! Apesar de a maestrina na Bélgica também ter padrões musicais muito altos. É muito interessante...eu acho que provavelmente as crianças belgas eram mais livres nos seus movimentos, certo? Você sentiu isso? Na sessão dos movimentos eu acho que eles pareciam um pouco mais livres.... Eu não sei, eu nunca pensei sobre isso... Eu teria pensado o contrário porque na Europa as crianças são mais "educadas", os modos europeus e tudo mais... E as crianças do YPC são new yorkers, então, você sabe, tudo é possível com new yorkers... Na verdade, eu teria pensado o contrário, mas eu nunca vi os dois vídeos juntos para ver a diferença. As crianças belgas eram muito doces. Minha companheira ${ }^{13}$ era holandesa, do sul da Holanda onde se fala o holandês que é próximo do flamengo, mas sempre quando eu tentava falar as poucas palavras que eu sabia as crianças diziam: "Isso não é flamengo, é holandês". Vou the contar outra coisa interessante sobre o processo [na Bélgica]: as crianças ficaram todas juntas por semanas em um dormitório. Elas não iam para casa. Não me lembro quantos dias foi o período de ensaio, mas eles tinham quartos para elas. E elas comiam juntas e isso foi muito interessante também. As crianças de Nova York, é claro, tinham que ir para casa e tinham vidas ocupadas, escola e tudo mais. Na Bélgica foi uma época específica em que eu acho que elas não estavam na escola, então tivemos tempo para fazer algo assim.

\section{Isso é bem interessante. No mesmo vídeo que mostra o processo do Dancing Voices você diz: "sempre dou permissão para as crianças serem elas mesmas, para encontrarem sua própria criatividade."}

Sim, eu tento. Eu sempre sinto falta da individualidade, especialmente com crianças, em um coro, esse tipo de corpo de orquestra. Quero dizer, eu sinto vontade de ver aqueles diferentes seres, mesmo que seja em um grupo de

${ }^{13}$ Mieke van Hoek (1946-2002), coreógrafa. 
pessoas. Eu e Yoshi14 trabalhamos nos figurinos para que não tivéssemos todo mundo vestindo uniforme. Nós fizemos uma roupa para cada criança, algumas da mesma cor, mas cada criança tinha uma qualidade única. Isso é algo muito importante para mim. E, também, elas puderam se sentir livres para realmente trabalhar em seu próprio movimento, porque eu não dei a elas uma coreografia específica. Demos padrões, mas não coreografias. A música também é muito precisa, mas com o meu grupo [ensemble] sabemos onde podemos nos divertir, então tentei transmitir isso o máximo que pude para elas. Mas acho que elas estavam apenas tentando fazer o certo, sabe? É uma coisa de criança, por causa do nervosismo e tudo mais. Mas, o modo que algumas dessas músicas soam com o YPC, acho que nunca ouvi soar melhor, seja por adultos como por crianças. Para mim, é assim que deve soar, do jeito que elas fazem. É tão bonito.

Você fez muitos trabalhos inspirados em crianças ou sobre crianças. Eu tenho em minha lista - Children; Quarry, Education of the Girlchild, Book of Days, Three Heavens and Hells e The Politics of Quiet. Por que as crianças estão tão presentes no seu trabalho?

E, também, em Juice ${ }^{15}$ tinha crianças no Museu Guggenheim na versão do início de 1969. E em Ascension Variations em 2009. Eu estava trabalhando nisso e pensei: algo está faltando aqui, não há crianças na peça. Então, Debbie Lee Cohen, que estava me ajudando com a parte visual [cenários e peças da instalação], tinha duas meninas, de sete e cinco anos, e eu fiz uma coisa especial para elas. Foi muito importante tê-las no trabalho. Eu sempre gostei de ter pessoas de todas as idades nas minhas obras. Mesmo quando eu era jovem, eu tinha pessoas muito velhas nas peças. Porque eu realmente quero ter o espectro da vida no meu trabalho. Mas, com as crianças, acho que tem mais a ver com um tipo de estado com o qual todos nós começamos [a vida], mas depois temos uma obstrução daquilo que tínhamos originalmente. Por exemplo, no pensamento budista todos nascemos com tudo, nós nascemos perfeitos. Quero dizer, às vezes tem pouco de resíduo de outra vida, mas basicamente nossas

14 Yoshi Yabara, figurinista.

15 Juice: a theatre cantata in three installments (1969). 
mentes naturais estão lá e então a nossa experiência começa a obscurecer aquilo. E, assim, você passa anos meditando para voltar à mente natural que as crianças têm originalmente. E é muito interessante, como eu não tive meus próprios filhos, assistir minha sobrinha neta e meu sobrinho neto desde que eram bebês e ver como isso começa a chegar, ver como no início eles foram muito abertos a tudo e então, de repente, é muito como: "é só isso, mas não aquilo". Segundo o pensamento budista essa é a próxima coisa que acontece: a construção do ego. Estamos todos muito abertos a tudo, não estamos discriminando de uma forma ou de outra, apenas estamos abertos à experiência e, aos poucos, começa a surgir "isso é bom, isso é ruim", "eu gosto disso, eu não gosto daquilo." E vamos ficando cada vez mais fechados. Eu tenho observado isso, especialmente na menininha. É tudo sobre controle. Aos poucos eu acho que ela está se abrindo um pouco novamente, isso também pode ser um estágio no desenvolvimento infantil onde você está tentando proclamar sua identidade. Mas essa identidade também é, de certa forma, falsa. Essa é a parte triste disso. Essa ideia de quem pensamos que somos que é muito rígida. Nossa identidade não depende disso, de gostarmos de vermelho ou azul, preto ou branco. A identidade é, na verdade, mais fluida, e os pequenos sabem mais sobre isso. É tão interessante, né? Sinto que parte do fazer artístico é voltar a essa pureza e essa honestidade, não ter medo disso. Esse é um dos meus objetivos.

\section{Isso é muito bonito. Quais são as particularidades de ter crianças no palco?}

Bem, por exemplo, em The Politics of Quiet isso foi bastante desafiador. Tínhamos que ter crianças de cada lugar que íamos, e elas tinham níveis variados de capacidade de concentração. Às vezes era um pouco doloroso, porque eu as colocava talvez não em uma situação tão "infantil" [chidlike]. Eu dava a elas tarefas. Alguém poderia dizer que é uma coisa boa de se fazer, porque essa maneira de atuar cumprindo tarefas é muito estimulante. Você pode apenas se concentrar no que está fazendo, não está tentando fazer mais nada. Mas acho que para algumas delas a concentração era um pouco difícil, estar na frente de 
todas aquelas pessoas... Em Book of Days, Toby ${ }^{16}$ e Hannah ${ }^{17}$ foram exemplos incríveis para todos nós. Quando estávamos prontos para filmar, elas sempre estavam lá. Estávamos todos amontoados em volta do aquecedor, estava muito frio, estávamos na França e elas estavam sempre prontas. Elas realmente lidaram com isso muito bem. Então eu não sei. Eu simplesmente amo trabalhar com as crianças. Não preciso tê-las em todas as peças, mas é muito especial.

\section{O que uma artista pode aprender com as crianças? O que você aprendeu com as crianças com as quais trabalhou?}

Eu acho que é essa coisa de estar completamente presente no momento. Algo que sempre tentei. E não fazer nada extra, apenas ser muito claro e honesto. Eu acho que as crianças são tão honestas, basicamente. Então, acho que qualquer artista pode aprender estando perto deles. Na peça Children, que foi a parte em filme de uma peça ao vivo chamada Excerpt from a work in progress, quatro daquelas crianças eram minhas alunas em New Jersey, apenas a quinta era filha de uma amiga minha - ela é a mulher no filme. E elas também foram extraordinárias no seu comprometimento. Penso que isso é outra coisa sobre as crianças: uma vez que se comprometem com alguma coisa, elas fazem isso cem por cento. Primeiro, elas precisam se comprometer, elas precisam decidir que é isso que eles querem fazer, mas quando o fazem, eles dão tudo o que têm. E eu só me lembro daquelas crianças serem tão maravilhosas. Uma das crianças estava com muito medo de descer a escada rolante. Você não consegue ver no vídeo, mas eu estava sentada segurando as pernas dela na escada rolante enquanto ela descia, porque ela estava aterrorizada. E, no entanto, ela decidiu fazer isso. Eu acho que a franqueza que as crianças têm é algo que todos nós podemos aprender.

O que você acha que as crianças podem aprender trabalhando com você?

\footnotetext{
16 Toby Newman.

17 Hannah Pearl Walcott.
} 
Eu acho que as crianças do YPC ... Primeiro de tudo, meu trabalho, por causa da combinação de canto e movimento, é um pouco como bater na cabeça e esfregar a barriga, é a coordenação disso. Mas, de certa forma, acho que se torna muito natural para elas. O que eu amo em Francisco Núñez é que ele realmente treina as crianças na tradição da Europa Ocidental com muito rigor, mas depois, porque ele é dominicano, ele volta ao corpo. Então, acho que, de certa forma, meu trabalho permite que, mesmo de uma forma muito séria, precisa e rigorosa, elas possam voltar à sua exuberância natural, alegria e movimento, voz e corpo como um só. Geralmente, elas têm apenas que ficar de pé e cantar, o que eu acho bastante antinatural. Então, de certa forma, acho que meu trabalho as traz de volta à sua fonte natural de energia. Libera-as e, ao mesmo tempo, é uma combinação de liberdade e disciplina.

Eu li muitas das suas entrevistas e o jeito que você fala sobre o seu trabalho tem muito a ver para mim com os modos de ser e estar das crianças no mundo. Por exemplo, a exploração da materialidade da voz ao invés do significado das palavras, o ser brincalhão no processo criativo, a exploração de diferentes modos de percepção, a fluidez e o foco ao mesmo tempo. Você já pensou sobre isso?

Não. Não conscientemente. Quero dizer, de tempos em tempos, é claro. Sinto que perdemos tanto quando envelhecemos e nos adaptamos à sociedade. A sociedade interrompe muito da fonte de nossa energia, nossos corações, nossas conexões. Conexão é tudo. Eu sempre digo que inteligência é fazer conexões. É disso que se trata a inteligência. Quanto mais conexões as pessoas puderem fazer, mais inteligentes elas são para mim. E acho que a sociedade nos encoraja a desconectar. Desconectar de nossos corpos e nos compartimentar. As crianças têm essa sensação do tempo, o fluxo do tempo. Eles não compartimentam suas mentes. Eles apenas fluem de uma coisa para a outra. Certamente de tempos em tempos tenho muita consciência de ir realmente contra o que a sociedade está tentando fazer conosco. E acho que, como artistas, estamos sempre respondendo de uma maneira ou de outra. Não acho que meu trabalho seja excessivamente político, mas sinto que simplesmente fazer arte agora já é político. Para realmente incentivar valores que agora estão sendo afastados de nós neste mundo, voltar a esses valores. E um dos valores é a integração corpo 
e mente, voz e corpo, conectar tudo. E acho que as crianças têm isso naturalmente.

A cena de Book of Days em que a mãe cata piolhos da cabeça das filhas me trouxe várias memórias. Recentemente eu me dei conta que me sinto tão bem quando vejo vídeos de ASMR porque... Você já ouviu falar dos vídeos de ASMR?

Não. O que é isso?

ASMR significa Autonomous Sensory Meridian Response.

Alguém me falou sobre isso. O que é?

É uma sensação de bem estar combinado com formigamentos no couro cabeludo em resposta a um estímulo específico, geralmente um som.

E você vê isso na internet? Você usa fones de ouvido?

Sim. Tem vários vídeos na internet. Mas eu tinha essas sensações quando eu ouvia alguns sons específicos desde que eu era criança.

Ah, isso faz muito sentido.

Então, recentemente eu me dei conta que eu me sinto tão bem quando vejo vídeos de ASMR porque eu tenho a mesma sensação que eu costumava ter quando eu era criança e minha mãe catava piolhos na minha cabeça.

[risos] Nossa! Isso é ótimo. Eu amei. É lindo.

Eu costumava ficar sonolenta, super relaxada e ter essa sensação de formigamento no couro cabeludo. Você poderia falar sobre as imagens com as crianças no filme? Alguma delas tem relação com a sua infância?

Na minha infância eu não lembro de ninguém catando piolhos na minha cabeça [risos]. Acho que eu estava tentando trazer à tona a beleza das coisas mais comuns do dia-a-dia. "O que teria acontecido na Idade Média?” É nisso que eu estava pensando. Em grande parte do meu trabalho eu gosto de delinear a 
magia do comum, do ordinário. A magia das coisas muito simples. O cuidado de uma mãe... a sensação de toque são coisas que eu acho realmente importantes.

\section{Sim, é tão bonito. Você poderia falar sobre a sua relação com Toby Newman? Vocês trabalharam juntas em outras produções?}

Bem, ela está trabalhando em um grupo chamado The M6, que é um grupo concentrado no meu livro de músicas. A história da audição de Toby é tão boa. Eu estava procurando uma menina para a personagem principal de Book of Days. Eu e as produtoras Catherine ${ }^{18}$ e Dominique ${ }^{19}$ estávamos indo em vários centros judeus e muitas crianças vinham para a audição, mas elas eram tão desagradáveis. [risos] Elas diziam: "agora vou cantar People". E elas cantavam muito bem. E depois elas diziam: "E eu cantarei novamente para você, se você quiser". E eu ficava tipo: "Ah, não. Não precisa." Então, estávamos quase desistindo. Catherine conhecia um professor na Little Red School House, que é uma escola primária, acho que é uma escola particular, em West village. Tínhamos acabado de ver um dia inteiro com essas meninas e, então, ela o levou para jantar, e estava reclamando, e ele disse: "Eu conheço a garota certa para você". Toby entrou aqui no loft e não estava toda produzida, ela usava uma camisa xadrez e tranças. Ela cantou uma linda canção de ninar da nossa música folclórica. Eu pensei que ia desmaiar e então disse a ela: "Você gostaria de cantar de novo?" E ela disse: "Não!" E eu fiquei tipo: "Você conseguiu o papel!" Ela era ótima e também trabalhava em composição musical, eu não sei se ela ainda não faz isso. Ela foi ao piano e começou a tocar. Ela era a criança! Foi isso. Eu simplesmente amo que ela tenha dito: "não, não vou fazer isso de novo". E que ela não estava: "Posso cantar de novo? Quero o papel. Quero o papel. Posso cantar dezenove canções pop?" Ah, meu Deus. Esse é o outro lado disso. A cultura está fazendo com que crianças de cinco anos já percam a infância. Eu tento dizer o máximo que posso aos jovens, mesmo aos adolescentes: "Apenas mantenha sua infância o máximo que puder. você tem tempo de sobra para crescer."

\footnotetext{
${ }^{18}$ Catherine Tatge.

19 Dominique Lasseur.
} 
Em Book of Days, o contador de histórias é questionado: "Por que um homem como você escolheu essa profissão em particular?". Peter Brook esteve aqui em novembro passado com uma bela peça intitulada Why? Por que fazer teatro? Por que ser um artista? Eu fui ver uma conversa com ele, e foi tão bonito ver aquele homem de 94 anos falando sobre sua vida na arte. Para você, depois de tantos anos nas artes cênicas, qual é a sua resposta para isso? Por que você escolheu essa profissão em particular?

Eu acho que ela me escolheu. Foi uma escolha sem escolha, na verdade. Lembro-me dos momentos em que assumi o compromisso, ou que voltei a me comprometer. Quando eu tinha cerca de 22 ou 23 anos, lembro-me de um dia dizer: "Eu vou só me deitar aqui e no final do dia, se eu decidir que não vou ser artista, será isso. E se eu decidir que vou ser artista, será isso." E no final do dia eu decidi me comprometer. Houve momentos em que recomecei a minha vida. Mas, pensando bem, basicamente dediquei minha vida inteira a essa loucura. A pergunta: "por quê?". Não faço ideia. Foi uma jornada maravilhosa. Eu adoro música e adoro movimento. Acho que é assim que eu posso expressar meu amor. Então eu escrevo essas pequenas canções para as crianças, minhas músicas de aniversário. Eu posso expressar meu amor estando totalmente presente quando estamos juntos, mas posso expressar meu amor ainda mais escrevendo músicas para elas. Esse tem sido o meu privilégio: poder expressar meu amor do meu jeito na vida. E as pessoas estão interessadas em ver essa expressão de amor. Peter Brook disse o porquê? Ele disse ou não?

Não exatamente...

[risos] Ah, ok! É difícil. Você recebe um chamado...

Na verdade, ele também falou sobre o amor... 
Você viu o vídeo do $A T L A S^{20}$ ? Todo o primeiro ato é sobre a Alexandra criança, quando ela recebe o chamado. É uma espécie de símbolo disso, são os seus guias, [que aparecem] como um cavalo. Mas é muito sobre a ideia de que todos nós somos chamados por espíritos, de uma maneira ou de outra. Não importa o que é. Eu poderia ser uma artista ou uma enfermeira, ou uma boa dona de casa, mas todos nós recebemos o chamado. E então algumas pessoas respondem a isso e outras não. E aqueles que não, acho que geralmente acabam sendo muito infelizes. Então, é isso o que quero dizer com escolha. Se eu pensar em quando eu era jovem, é um mistério de onde eu tirei forças. Mas de alguma forma, por mais insegura que eu fosse quando jovem, eu sabia lá no fundo que seria passo a passo. E, basicamente, sinto que, durante toda a minha vida, eu tentei seguir passo a passo o meu caminho, seja o que for. E eu nunca sei o que é. Especialmente quando você não vem de uma tradição... Eu me lembro de ter visitado uma cerimônia do chá japonesa. Um jovem, que era mestre em cerimônias do chá, compareceu à minha apresentação e fez uma cerimônia do chá para nós. Lembro que conversamos sobre como a cerimônia do chá é uma tradição. Eu não tenho uma tradição. A minha seria a tradição de procurar [mine is more the tradition of being an explorer]. Então, nos períodos entre os tempos em que estou inspirada vem o "e agora?" E, então, eu tenho que encontrar novamente. Eu sempre posso voltar a trabalhar a minha voz e o meu corpo até que a próxima inspiração venha, mas é como se eu estivesse tentando encontrar o caminho na medida em que caminho. Então, você pode dizer que talvez essa seja a tradição do pioneiro, do explorador, ou algo assim. Sinto que isso é tudo o que sei na minha vida: o como fazer isso. Porque toda vez que não sigo isso, meu corpo responde e fico muito infeliz.

\begin{abstract}
$\mathrm{Na}$ entrevista para John Killacky, quando você está falando sobre o relacionamento entre Eva e o avô, você diz: "ela está tentando falar sobre imagens do futuro, e ele interpreta como se fossem do passado." Você acha que existe uma lacuna de comunicação entre diferentes gerações? Crianças e jovens podem ver coisas que, como adultos, não podemos mais?
\end{abstract}

20 ATLAS: an opera in three parts é uma ópera em três atos composta por Meredith Monk, que escreveu também o libretto e coreografou as danças do espetáculo que estreou na Houston Grand Opera (EUA), em fevereiro de 1991. A história é baseada na vida e obra da exploradora francesa Alexandra David-Néel. 
Eu acredito. E acho que esse é um arquétipo que usei muito em meu trabalho, um tipo de personagem visionário outsider que não é compreendido. Nesse sentido, poderia ser a criança ou o avô, mas também poderia ser um artista. Essa ideia aparece em diferentes fases do meu trabalho. Porque eu acho que os artistas são como a antena da nossa sociedade. Eles estão, de certa forma, nas extremidades da sociedade para poder observá-la, não na cultura dominante. Eles não são apanhados pela cultura dominante. E isso pode ser uma ideia romântica da minha parte, porque talvez as pessoas não pensem mais nisso. Talvez você possa dizer que Lady Gaga é uma visionária, mas acho que não. Eu acho que esse tipo de pessoa está refletindo a sociedade mainstream. Isso por um lado, por outro lado você pode ser um artista subversivo nesse mainstream. Mas acho que sempre achei o visionário um tipo de personagem arquetípico, então é isso que Eva é em Book of Days. Ela vê, mas é bastante doloroso para ela. Então, a pessoa com quem ela realmente pode se comunicar é outra pessoa um pouco estranha, é a Mulher Louca [Mad Woman]. Ela é um outro tipo de personagem visionária, um pouco fora da sociedade. Então elas podem se comunicar e, de certa forma, ela é uma visionária avançada e a Eva é uma visionária iniciante. A Mulher Louca se torna sua professora espiritual.

\section{Você poderia falar mais sobre essa cena?}

Com a personagem Mulher Louca, eu estava tentando também passar a ideia de que, às vezes, pessoas consideradas loucas veem coisas que outras pessoas não veem. Mas isso não significa dizer que não conheço pessoas que são realmente doentes mentais, o que é bastante doloroso. Então, você tem que ter muito cuidado com isso, porque eu conheço pessoas que realmente tiveram muitos problemas e que não são visionárias, é apenas sofrimento. Mas às vezes as pessoas que você pode considerar um pouco estranhas, veem coisas que não vemos. Como as pessoas autistas. Às vezes, elas veem as coisas de uma maneira diferente e podem fazer coisas que as outras pessoas não podem fazer. São 
apenas maneiras diferentes de percebermos as coisas. Eu acho que aquilo me pareceu a iniciação da criança em saber que o que ela está vendo tinha verdade. De certa forma, ela é uma aprendiz da Mulher Louca. É por isso que ela a faz varrer. A Mulher Louca é um pouco dura. E quando elas fazem a dança juntas o que foi muito divertido, vou the contar como fiz essa dança - você vê que elas têm um relacionamento muito profundo. Dar à criança a confiança de que a sua visão também tem verdade, foi assim que eu vi essa cena.

\section{Quando a Mulher Louca olha para ela, é tão bonito.}

Sim. Nas danças, a tarefa da Toby era me acompanhar e a minha tarefa era fazer com que ela não pudesse me acompanhar. Eu continuava mudando o que estava fazendo, me movendo, e ela tinha que tentar acompanhar. Tínhamos duas tarefas opostas e acho que foi isso que deu aquela energia [para a cena].

Eu tenho uma última pergunta. Gostaria de lhe perguntar sobre o seu legado. Quando conversei com o Peter ${ }^{21}$, a palavra legado surgiu algumas vezes quando ele falava sobre os jovens do High School Program ${ }^{22}$. Você poderia comentar isso?

Bem, penso que é mais uma linhagem do que um legado, em particular porque sinto que me mantive muito distante de criar uma técnica codificada. Eu sinto que isso é morto, seja como for. Quando a pessoa morre é como se você visse apenas a casca dessa pessoa, quero dizer, isso nunca leva a lugar algum. Então, eu sinto que o que tento deixar para trás com os jovens é quase uma filosofia de vida, uma maneira de pensar sobre as coisas, uma maneira de pensar sobre a nossa relação com a vida, uma maneira de pensar sobre uma vida de aprendizado, curiosidade e investigação, uma vida de coração aberto, mais do que uma técnica em particular. A alegria de aprender, na verdade. E penso nisso como linhagem, porque acho que deve ser transmitido. Uma transmissão de pessoa para pessoa, e não como um tipo de técnica codificada.

\footnotetext{
${ }^{21}$ Peter Sciscioli é consultor de educação da The House Foundation for the Arts. Artista interdisciplinar (dança, música, teatro e cinema), criador, educador e produtor, Peter trabalha com Meredith Monk desde 2003.

22 Programa formativo destinado a jovens do ensino médio da cidade de Nova York.
} 


\section{Referências}

ABRAMOWICZ, Anete. Estudos sobre a criança e a infância: nas fronteiras entre a Sociologia e a Educação. In: OLIVEIRA, Fabiana Luci de; RODRIGUES, Tatiana Consentino (Orgs.). Conversas metodológicas. UFSCar, 2016. Disponível em: <http://www.neab.ufscar.br/?page_id=5744>. Acesso em: 14 ago. 2019.

ABRAMOWICZ, Anete e OLIVEIRA, Fabiana. A sociologia da infância no Brasil: uma área em construção. In: Educação, Santa Maria, v. 35, n. 1, p. 39-52, jan./abr. 2010.

AGAMBEN, Giorgio. Infância e história. Buenos Aires: Adriana Hidalgo, 2001.

Recebido em: 29/06/2020

Aprovado em: 06/08/2020 